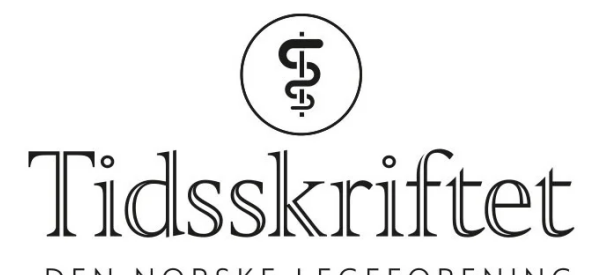

DEN NORSKE LEGEFORENING

\title{
Seksjon for behandlingsreiser svarer
}

\author{
KOMMENTAR
}

YNDIS STAALESEN STRUMSE

ystrumse@ous-hf.no

Yndis Staalesen Strumse er medisinsk rådgiver/MD ph.d. ved Seksjon for behandlingsreiser, Oslo universitetssykehus, Rikshospitalet.

Forfatteren har ikke oppgitt noen interessekonflikter.

Takk for ditt initiativ til debatt. Du etterspør oppdatert dokumentasjon på våre psoriasispasienters grad av utslett ved ankomst på en behandlingsreise. Vi samler vi for tiden data på PASI som en intern kvalitetssikring, men dette foreligger per i dag ikke som dokumentasjon på vitenskapelig nivå. Vi anser det her som vesentlig at datainnsamlingen pågår i minimum et helt år, siden det vil kunne være variasjoner mellom gruppene, bl.a. påvirket av årstid. Vi vil understreke at våre uttakskriterier vedrørende PASI ikke er blitt endret. Pasientene mottar instrukser om intensivert avskjellende behandling før utreise for effektiv utnyttelse av behandlingsoppholdet. Sistnevnte forhold vil kunne medvirke til lavere PASI ved ankomst i forhold til søknadstidspunkt.

Det er verdt å merke seg at selv om behandlingsreise en gang ble iverksatt som et alternativ til sykehusopphold i Norge, er det funnet en ikke ubetydelig tilleggseffekt av klimaforskjellen, samt effekten av den helhetlige tilnærmingen vi i dag tilbyr i dette behandlingsprogrammet. Dokumentasjon av denne effekten foreligger ikke bare på PASI, men også på flere andre nivåer av helse, helt ned på cytokinnivå (1). Les gjerne mer om vår forskning på vår hjemmeside https://oslo-universitetssykehus.no/avdelinger/direktorensstab/stab-fag-pasientsikkerhet-og-samhandling/avdeling-for-utenlandskontor-ogbehandlingsreiser/behandlingsreiser\#forskning-pa-effekt-av-behandlingsreiser 
1. Søyland E, Heier I, Rodríguez-Gallego $C$ et al. Sun exposure induces rapid immunological changes in skin and peripheral blood in patients with psoriasis. Br J Dermatol 2011; 164:344-55. [PubMed] [CrossRef]

Publisert: 4. mai 2020. Tidsskr Nor Legeforen. DOI:10.4045/tidsskr.20.0296

(C) Tidsskrift for Den norske legeforening 2023. Lastet ned fra tidsskriftet.no 26. april 2023. 